\title{
Reviewing the Employment Difficulties of Chinese Female College Students Majored in Humanities
}

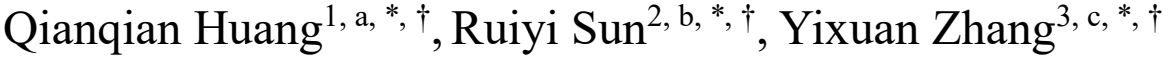 \\ ${ }^{1}$ School of Education, Sheffield University, Sheffield, South Yorkshire (S10 2TN), U.K. \\ ${ }^{2}$ School of English, Zhejiang Yuexiu University, Zhejiang (312000), China \\ ${ }^{3}$ School of Foreign Languages, Shanghai Ocean University, Shanghai, Shanghai (201306), China

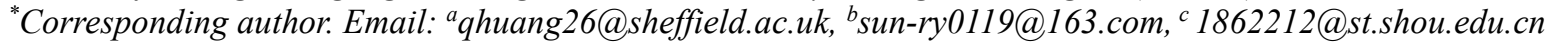 \\ These authors contributed equally.
}

\begin{abstract}
Gender theory has developed from sex to gender with the progress of the times and social culture. People rely on it for gender identity and gender expression in daily life. However, gender inequality caused by gender stereotypes still exists in large numbers. Especially in the work and employment of women, they are still limited by their self-gender identity and social-cultural gender culture in their contemporary study and life. Therefore, this study discusses the current discrimination and prejudice faced by women based on secondary data analysis. Simply, it explores the reasons why female college students majoring in humanities and social sciences suffer from gender inequality and discrimination, as well as the challenges and improvement measures they face in the employment environment. By reviewing domestic and foreign research literature, this study found that the root of female gender inequality and discrimination lies in patriarchy. In addition, the study also finds that China's social and cultural concepts and different expectations of men and women limit the employment choices of female college students. Similarly, the persuasion of family members and the yearning of female college students for ideal occupations and developed regions are also important factors influencing employment. Based on these findings, this study makes recommendations from three perspectives, which help female college students majoring in humanities and social sciences improve their employability and change society's gender bias against women. First, the female colleges must give full play to their academic advantages and establish a correct outlook on employment. Second, the country and government need to give strong support. Third, companies and employers change recruitment conditions to accept more high-quality women.
\end{abstract}

Keywords: Gender theory, Gender Inequality, Employment Environment, Society's Gender Bias, Female College Students.

\section{INTRODUCTION}

Since the college entrance examination system resumption in 1977, China's higher education has developed nearly 40 years in parallel with reform and opening. The enrollment expansion of colleges and universities started in 1999. In 2000, colleges and universities stopped the distribution system of undergraduates, and the new employment system was fully implemented across the country (graduates "twoway choice, independent career choice"). Under the conditions of a market economy where resources are reallocated, the traditional gender division of labor is intertwined with the employment opportunity gap formed by the economic downturn in recent years, which results in the overall pressure of college students' employment to be continuously passed on or superimposed on the group of women college graduates, causing more noticeable and more severe problems. With the gender exclusion and inequality of women college students in the job market, the employment problem of college students eventually evolved into the gender problem of college students' employment or the difficulty of employment of women college students. This article will focus on the employment problem of women college students by describing the social construction of the theoretical framework of the women gender, exploring the reasons for the difficulty of employment of Chinese women college students, and giving adjustment measures from the perspective of government enterprises and individuals. 


\section{GENDER THEORY AND SOCIAL CONSTRUCTIVISM}

Sex refers to biological characteristics (e.g., genitals, internal reproductive organs, chromosomes, hormones, etc.), specifically distinguishing between males and women from an anatomical point of view [1]. With the wave of the feminist movements, social constructivism questioned essentialism, which involves biological sex determination, and criticized the view that women's genes are more vulnerable than male genes [2]. Factors such as social culture are gradually being considered as factors in the construction of gender. In other words, people's gender identity and gender expression in daily life depend on the social attributes of gender. People rely on gender and gender symbols (i.e., masculinity, femininity) to express and identify other people's and gender symbols [3]. That means that after the biological characteristics of the first Sex (i.e., male) and the biological characteristics of the second Sex (i.e., women), the third sex characteristics (gender temperament, degree of gender difference) play an essential role in forming gender identification and opposition [4]. It is worth noting that although the concept of cognition of gender has advanced which from Sex to gender, gender inequality caused by gender stereotypes still exists in large numbers. As Fine pointed out, understanding the process of gender formation is crucial, which is the key to overcoming essentialist gender concepts [2]. This part will describe the gender growth process of women and the obstacles that women may encounter due to gender issues.

As Beauvoir pointed out, women are not born to be women but become women in the process of growing up [5]. In this regard, Cusack gave a specific statement, an essential factor of women's subordination is systemic conditioning, which originated in the family and society [6]. The gender structure of women is assigned to gender categories according to the appearance of their genitals at birth [7]. At the same time, parents will also confirm gender distinctions by using names, clothing, and other gender markers. Once the child's gender is apparent, other people will treat the child in different ways, the child will also respond to different treatments, and the child will find members of the same gender at this time. When women enter puberty, sexual feelings, desires, and practices are shaped by social gender norms and expectations. For example, the stereotype that women are not suitable for studying mathematics is one of the discriminations shown in research. Also, there are other studies based on their women's stereotypes [8-10]. Furthermore, this gender-based setting has primarily caused women learners' feelings of powerlessness and anxiety in the learning process. Although Mueller et al. pointed out, the intellectual difference between men and women is only the natural result of their education and the environment, the idea of IQ equality did not catch on in the minds of the general public [11]. Overt gender discrimination and gender inequality have improved, but hidden gender discrimination and gender inequality still exist. Moreover, when girls become women, their already formed gender concepts and gender culture will affect their social life. It is worth noting that the employment issue has become a significant event that adult women need to face. Several studies [12-14] have shown that women's work is closely related to their gender roles and the cultural connection between women and the "internal" family. In contrast, men are "external," earn a living and exercise political and economic power.

On the one hand, due to gender inequality and discrimination, its root lies in patriarchy [15]. Compared with Western countries, China's patriarchal culture can be traced back to the social and cultural foundations of the early dynasties (i.e., the three obediences and four virtues, women are a subsidiary of men). What is gratifying is that although the rise of women's consciousness has only developed in recent years, the status of women has continued to improve. On the other hand, DeCecco et al. believe that although physical gender is inherent, social gender is neither inherent nor fixed. It is the product of interaction with society and will change with time and cultural changes [16]. Women are still subject to the limitations of self-gender recognition and social-cultural gender culture in contemporary study and life. However, more and more women tend to develop themselves into the fourth gender feature, which is hermaphrodite [2].

According to the latest information released by the Ministry of Education of China, in 2017, the number of college graduates reached 7.95 million, which was more than 300,000 more than the 7.65 million in 2016, a record high, entering a more difficult employment season in history. Moreover, this trend has been severe year by year. The number of college graduates in 2021 is expected to reach 9.09 million. In China's employment environment where supply exceeds demand, the employment situation of female college students is not optimistic, and especially female college students who majored in humanities. This article will next focus on the reasons for the difficulty in obtaining employment for female liberal arts college students.

\section{REASONS OF WOMEN'S EMPLOYMENT DIFFICULTIES}

In addition to the above theory developing for gender awareness and gender differences of social consensus affect the employment and career selections of women college students who majored in humanities, employment difficulties also come from themselves and Chinese society norms, especially during COVID-19. 


\subsection{The Gender Discrimination of the Recruiting Unit.}

Qian refers in SWOT (Strengths Weaknesses Opportunities Opportunities Analysis of Employment of women College Students in Humanities and Social Sciences) that the challenges they faced are unfair factors in the employment environment and gender discrimination in people's traditional ideas [17]. In China, most people may have the wrong traditional concept of "son preference"; therefore, they will despise the career ability of women college students, especially those majoring in humanities and social sciences. Due to their limitations of professional knowledge about gender and sex, gender discrimination is more obvious in the process of employment. Mincer also claims that enterprise managers believe that women will leave the company because of nurturing children after working for a period, which pushes employers to prefer to choose men [18]. In their view, men can bring more social values than women because women have more "attachment costs", such as maternity leave, parental leave, etc. Even though, as it says, women in the workplace will not necessarily be affected by this, under the same level of ability, they should narrow the gender differences rather than selecting by gender. Employers should pay more attention to the evaluation of professional ability. Therefore, it is difficult for enterprises to achieve equal pay for equal work when recruiting. According to the survey report $\mathrm{Li}$, the average salary of fresh male graduates is about 1000 yuan higher than that of women fresh graduates for the same job [19]. Some enterprises cannot even effectively protect women's maternity insurance, maternity leave, parental leave, and other benefits, which they think has caused a burden to the company. This also forces women college students majoring in humanities and social science who intend to get married to reconsider their career choices. As in China's traditional society, when women get married, they are bound to take the responsibility of nurturing children. Then they are required to pay more attention to the family to take care of their husbands and raise their children, which makes it difficult for them to focus on the workplace or even leave the workplace. Most companies consider or consent to such potential risks when hiring.

\subsection{China's Social Concept of Male and Female Employment}

Gender theory holds that the gender role played by women is not determined by physiological factors but the product of social culture. Society and culture have different expectations about the division of roles and behaviors between men and women. Freeman \& Valletta believe that Chinese women and the public think that they are more suitable for stable positions such as nurses, secretaries, and teachers [20]. His career research showed that women account for $98 \%, 95 \%$, and $86 \%$ of professional fields, such as nurses, secretaries, and primary school teachers. These occupations are suitable for women college students majoring in humanities and social science. Especially under the influence of the COVID-19, many enterprises have experienced difficulties in development and even closed. For these women graduates, finding a stable job is the most important thing at present.

\subsection{The Persuasion of Family Members about Choosing Jobs}

The research by Wang \& Shi refers that women college graduates' view of choosing jobs is guided by their families [21]. Many parents are not highly educated, but they attach great importance to their daughters' education, and they pin all their unfulfilled wishes on their daughters. In their view, their daughter's purpose is to find a good and decent job after graduation. As a result, this kind of work reduces a lot of pressures in their daughters' life. For example, a stable salary and fixed working hours can guarantee women's economic level and life quality. The study by Wei \& Sun shows that most parents think that schools, hospitals, and other institutions or party and government organs are ideal work for girls [21]. Working in these places is stable and secure, which has fewer burdens on economics and time. Most parents want their daughters to work close to home and worry that girls are unsafe or bullied outside, which is the reason why parents do not want girls to work far away. In this case, they will always persuade their daughters to live nearby. Therefore, even though many Chinese women graduates majoring in humanities and social sciences have their own ideas, they may change their choices under the persuasion of their families or friends around them [22].

\subsection{Humanities and Social Science Women College Students' Yearning for Ideal Careers and Developed Areas}

Female college students are more likely to locate their ideal employment city in China's big cities, such as Beijing, Shanghai, and Guangzhou. As the employment opportunities and talent demand in these cities are relatively more abundant, even under the influence of gender discrimination, they can still find relatively satisfactory jobs. Du refers that most women college students prefer to develop in relatively developed cities, especially those coastal cities in the north and the south of China [23]. Also, Hao believes that these cities are rich in employment opportunities and resources, and almost all the good companies in China are concentrated in these areas [24]. The environment and the pattern of people are different, and there are many opportunities for personal growth. And the salaries and benefits in these places are much better than those in ordinary cities. For example, women college students can grasp the most timely 
employment information and changes of industries to adjust their career positioning and needs or improve their abilities correspondingly in relatively developed cities.

It can be seen that the gender discrimination of the recruiting unit, China's employment concept of men and women, family persuasion, and social science women college students' yearning for ideal occupations and developed areas will all affect their employment choices. Coupled with the impact of the spread of the epidemic, many women college students majoring in humanities and social science hope to find a stable job as soon as possible. Their families also hope that they can work in places away from home, making it more difficult for them to choose jobs.

\section{THE SUMMARY OF OVERSEAS AND DOMESTIC RESEARCH}

\subsection{Domestic Research}

Although Chinese domestic scholars have more studies on the employment discrimination of women college students, there is still a research gap on the employment of women college students who majored in humanities and social sciences. Domestic scholars' research on women students in humanities and social sciences mainly focuses on the social environment and students' professional problems, but there is still a lack of specific solutions.

\subsection{Overseas Research}

Foreign scholars have taken women's employment as the research focus. Still, due to cultural differences, there are few studies on the employment of Chinese women students in humanities and social sciences. Therefore, this provides a platform for our research. This paper will illustrate the employment problem of women college students in humanities and social sciences from three perspectives.

\subsubsection{From Personal Perspectives}

With the development and expansion of higher education, the employment situation of college graduates in China is becoming limited, which recruits fewer female students than before. Especially those who gender problems in employment have plagued are facing more difficulties. The disadvantage of women college students who majored in psychological characteristics imperceptibly influences their own career choice, but it does not mean women are not as excellent as men. They also have their own advantages, such as personality, language, communication, and slightly better than boys.

The solution of is that women should try their best to exert influences (e.g., excellent expression ability, language useability) than men. In the employment process, they should combine their own strengths with employment policies to find a suitable way of employment to change the gender bias of the society against women.

\subsubsection{From Government Perspectives}

To fundamentally solve the employment problem of women students who majored in humanities and social sciences, we should rely on individual students' efforts and need the strong support of the country and the government. First of all, the government can introduce relevant policies to improve the laws and regulations on equal employment and formulate policies that are conducive to women's competition in employment. Although there are laws clearly forbidding enterprises to restrict women's employment on the grounds of gender, there are many enterprises with gender discrimination. This shows that the law is not strong enough, and the relevant policies are not well implemented. Hence, the urgent task is to formulate a set of effective rules and policies. Foreign countries have designed a series of laws and regulations and social welfare policies to protect women's equal employment rights. Based on China's national conditions and social environments, the Chinese government can also give preferential policies to women college students, especially those majoring in humanities and social sciences. For example, it is possible to follow the example of the Swedish government, which established low-cost and high-quality childcare places through tax transfers to public services to ensure and actively encourage married women to engage in gainful employment. This practice has changed the traditional social division of labor to some extent. Married women can also enjoy the equal right to work instead of staying at home to take care of children and families.

\subsubsection{From Enterprise Perspectives}

Companies and employers should also change their recruitment requirements and resolutely abandon the behavior with prejudice against women. Enterprises can arrange women to appropriate positions according to the company's actual situation to maximize corporate interests. This can lay a good foundation for the development of the company and enhance the confidence of women in employment. At the same time, this requires the efforts of both the government and enterprises. The welfare of enterprises for women employees is also based on the corresponding government support for enterprises. The government can support companies that employ a certain number of women with policies such as tax cuts and other incentives. In this way, enterprises can improve the enthusiasm of hiring women, which is expected to further eliminate the discrimination and prejudice against women in recruitment. 


\section{CONCLUSION}

This paper reviews the employment difficulties of Chinese women college students who majored in humanities. By reviewing the literature, this paper analyzes the domestic and foreign scholars' data on the employment difficulties of Chinese women college students who majored in humanities and drew the reasons that affect their employment and the solutions. The main results of this paper are: 1) Describe the gender growth process of women and the obstacles that women may encounter due to gender issues; 2) Explain reasons of employment difficulties for Chinese women college students majoring in humanities from individual and society, especially during COVID-19; 3) Three suggestions on the employment of Chinese women college students majoring in humanities from governments, enterprises, and individuals. The problem of women's employment has always been the focus of attention of people and society. Based on previous research, this field has been extensively studied by many scholars. However, there is still a research gap in the employment difficulties of Chinese women college students who majored in humanities. This paper is expected to benefit women college students, especially those majoring in the humanities, to help them have better employment options and get out of the employment dilemma.

It is an important issue about how to realize the fair employment of Chinese women college students in the future, concerning the national economy and people's livelihood and the long-term peace and stability of the country. The purpose of this paper is to appeal to more social personages and scholars to actively give suggestions on the employment of Chinese women college students in humanities. It is believed that based on these three perspectives, the employment problem of Chinese women students who majored in humanities will be solved one day.

\section{REFERENCES}

[1] Muehlenhard, C. L., \& Peterson, Z. D. (2011). Distinguishing between sex and gender: History, current conceptualizations, and implications. Sex roles, 64(11), 791-803.

[2] Fine, C. (2010). Delusions of gender: How our minds, society, and neurosexism create difference. WW Norton \& Company.

[3] Manago, A. M., Graham, M. B., Greenfield, P. M., \& Salimkhan, G. (2008). Self-presentation and gender on MySpace. Journal of Applied Developmental Psychology, 29(6), 446-458.

[4] Shields, W. M. (1982). Philopatry, inbreeding, and the evolution of sex. SUNY press.
[5] De Beauvoir, S. (1949). El segundo sexo. La experiencia vivida, 2.

[6] Cusack, T. (2000). Janus and gender: women and the nation's backward look. Nations and nationalism, 6(4), 541-561.

[7] Lorber, J. (1994). Night to his day": The social construction of gender. Paradoxes of gender, 1, 1-8.

[8] Burgess, D., \& Borgida, E. (1999). Who women are, who women should be: Descriptive and prescriptive gender stereotyping in sex discrimination. Psychology, public policy, and law, 5(3), 665.

[9] Bobbitt-Zeher, D. (2011). Gender discrimination at work: Connecting gender stereotypes, institutional policies, and gender composition of workplace. Gender \& Society, 25(6), 764-786.

[10] Prentice, D. A., \& Carranza, E. (2002). What women and men should be, shouldn't be, are allowed to be, and don't have to be: The contents of prescriptive gender stereotypes. Psychology of women quarterly, 26(4), 269-281.

[11] Mueller, G., \& Plug, E. (2006). Estimating the effect of personality on male and female earnings. ILR Review, 60(1), 3-22.

[12] Silberschmidt,M.(2001). Disempowerment of men in rural and urban East Africa: implications for male identity and sexual behavior. World development, 29(4), 657-671.

[13] Quinn, N. (1977). Anthropological studies on women's status. Annual Review of Anthropology, 6(1), 181-225.

[14] Rowbotham, S. (2015). Woman's consciousness, man's world. Verso Trade.

[15] Makama, G. A. (2013). Patriarchy and gender inequality in Nigeria: The way forward. European scientific journal, 9(17).

[16] DeCecco, J. P., \& Elia, J. P. (1993). A critique and synthesis of biological essentialism and social constructionist views of sexuality and gender. Journal of Homosexuality, 24(3-4), 1-26.

[17] Qian, J. (2009). A SWOT analysis of the employment of female college students majoring in humanities and social sciences. China's out-ofschool youreducation, 2009: 2

[18] Mincer, J. (2001). Research on Human Capital.

[19] Li, T., Sun, N., Wu, ZH, \& Shan, N. (2020). An Empirical Study on the Employment Status of Chinese College Graduates under the Impact of the New Crown Epidemic. Journal of East China 
Normal University (Educational Science Edition), 38(10), 110.

[20] Freeman, R. B., \& Valletta, R. G. (2017). The Effect of Public Sector Labor Laws on Collective Bargaining, Wages, and Employment. NBER Working Paper, (w2284).

[21] Wang, Z., Shi, K., \& Gao, J. (2005). Analysis of influencing factors of college students' professional self-efficacy.

[22] Xu, W, \& Sun, X. L. (2008). Analysis and Countermeasures of Graduate Employment Psychological Problems. Human Resource Management, (012).

[23] Du, Y. CH. (2019). 58.3\% of respondents found that recent graduates around them are more willing to go to second-tier cities [N]. China Youth Daily, 201906-13

[24] Hao, X. F., (2010). Analysis of Employment Tendency and Reasons of Female College Students (Master's thesis, Dongbei University of Finance and Economics). 